\title{
The Declining Importance of Tradable Goods Manufacturing in Australia and New Zealand: How Much Can Growth Theory Explain?
}

Benjamin Hunt 



\title{
IMF Working Paper
}

Asia and Pacific Department

The Declining Importance of Tradable Goods Manufacturing in Australia and New Zealand: How Much Can Growth Theory Explain?

\section{Prepared by Benjamin Hunt}

Authorized for distribution by Ray Brooks

January 2009

\begin{abstract}
This Working Paper should not be reported as representing the views of the IMF. The views expressed in this Working Paper are those of the author(s) and do not necessarily represent those of the IMF or IMF policy. Working Papers describe research in progress by the author(s) and are published to elicit comments and to further debate.

In this paper, the IMF's new Global Economy Model (GEM) is used to estimate the contribution of unbalanced growth to the decline in the share of goods production in Australia and New Zealand. The simulation results suggest that faster productivity growth in the tradable goods sector in Australia, New Zealand, and their major trading partners accounts for a significant portion of the relative decline in the importance of goods production. Over the 1995 to 2004 period, unbalanced growth explains more than 80 percent of the decline in goods production in both countries.
\end{abstract}

JEL Classification Numbers: E23, F43, F47, L16

Keywords: Deindustrialization, Unbalanced Growth, Australia, New Zealand

Author's E-Mail Address:BHunt@imf.org 
Contents

Page

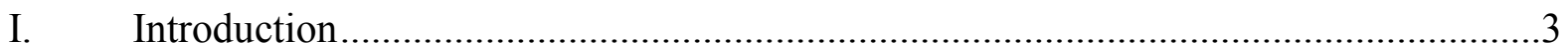

II. An Overview of The Global Economic Model ..........................................................4

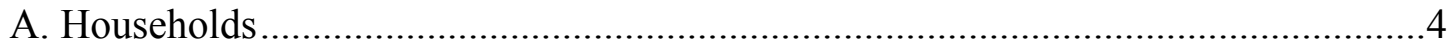

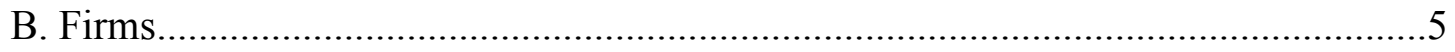

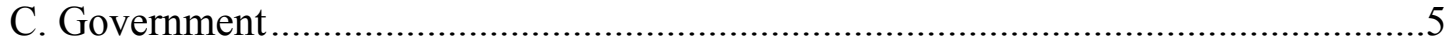

D. Parameterization........................................................................................

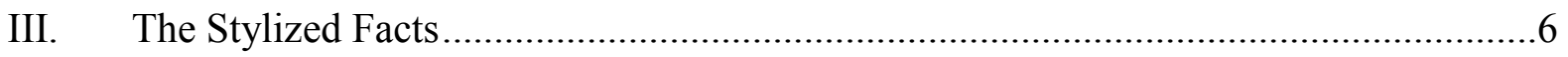

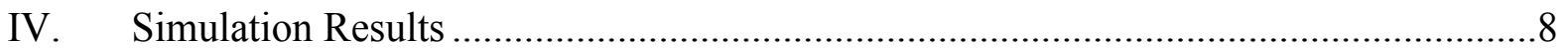

A. Some Broad Features of the Simulation Results.................................................

B. Effect of Unbalanced Growth on Tradables Production .......................................11

C. Internal and External Contributions ................................................................... 11

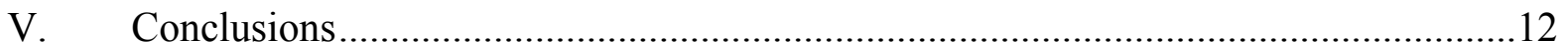

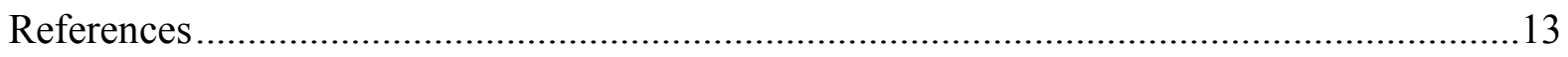

Tables

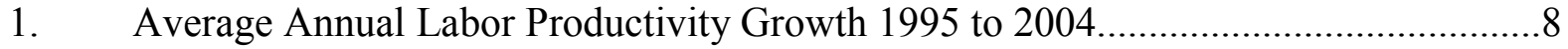

2. Change Over Ten Years in Share of GDP ......................................................11

3: $\quad$ Simulated Changes Over Ten Years in Share of GDP ........................................... 12

Figures

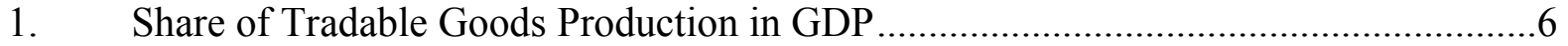

2. Annual Labor Productivity Growth ...............................................................

3. Some Broad Macroeconomic Consequences of Unbalanced Growth ........................10

Appendixes

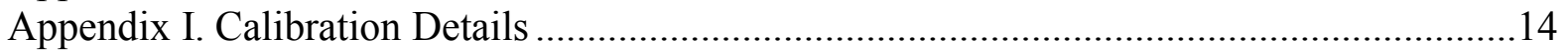

Appendix Tables

1: $\quad$ Key Steady-State Calibration Values................................................................. 14

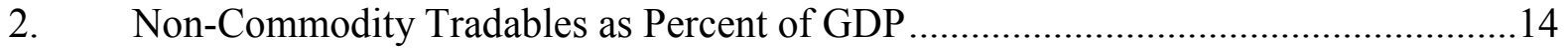

3. Production and Trade in Commodities as Shares of GDP .......................................15

4: $\quad$ Key Behavioral Parameter Values ..................................................................... 15 


\section{INTRODUCTION}

A common feature of economic development is the evolving composition of production. Early in the development process, the share of agricultural output in GDP declines and the share of manufactured goods increases (industrialization). Once economies reach a certain level of wealth, the share of goods production in GDP starts to decline and the share of services increases (deindustrialization). ${ }^{1}$ Although this evolution should be viewed as an integral part of the development process, concern still arises when traditional sectors of economies are perceived to be in decline. This concern can become particularly acute in open economies that experience large fluctuations in their exchange rates over the course of the business cycle. These fluctuations in competitiveness are often pointed to as causing permanent damage to traditional tradable goods sectors and the decline in their share of GDP is pointed to as proof.

Three theories are most often cited to explain the rising share of services in GDP in advanced economies. One is that demand for services is income elastic and as wealth increases with economic growth, the demand for services increases. ${ }^{2}$ Another is the unbalanced growth theory whereby faster productivity growth in goods production drives up the relative price of services, leading to their nominal share in GDP increasing. ${ }^{3}$ The final theory is related to miss-measurement, in that specialization has lead to traditional goods producers outsourcing services that were previously performed in-house. In this paper, a version of the IMF's Global Economy Model (GEM) is used to consider how much of the relative decline in the share of goods production in GDP in Australia and New Zealand over the 1995 to 2004 period can be explained by the second theory, unbalanced growth.

The simulation analysis suggests that faster productivity growth in the tradable goods sector in New Zealand, Australia, and their major trading partners, accounts for a large portion of the relative decline in tradable goods production. Simulating GEM over a ten-year period incorporating the productivity gap between the tradable and nontradable sectors seen between 1995 and 2004 results in a decline in tradable goods production in New Zealand of close to 3 percent, just under the $3 \frac{1}{4}$ percent seen historically. For Australia, the simulated decline in tradable goods production is $2 \frac{1}{4}$ percent, again slightly under the $23 / 4$ percent decline contained in the data. These results suggest that Baumol's unbalanced growth theory can in fact explain a large portion of the relative decline in tradable goods production leaving little to be explained by competing theories or competitive pressures from fluctuations in real effective exchange rates.

\footnotetext{
${ }^{1}$ Rowthorn and Ramaswamy (1999) estimate that once the per capita level for wealth hits roughly $\$ 9000$, deindustrialization commences.

${ }^{2}$ Early contributions to this explanation include Fisher (1935) and Clark (1940). More recent contributions such as Freeman and Schettkat $(2001,2005)$ focus on the "marketization" of household production as the key factor underlying the income elasticity of service demand.

${ }^{3}$ See Baumol (1967) and Baumol and others (1989).
} 
In addition to the impact on tradables goods production, the unbalanced growth simulation also matches two other features seen in the data for Australia and New Zealand over this period. The first is the impact on headline inflation. Tradable goods inflation declining and nontradables inflation rising is the key mechanism driving the relative shift in production shares. Initially, headline inflation falls as declining tradables price inflation more than offsets the rising nontradables inflation. However, as people learn more about the persistence in the productivity growth gap, headline inflation starts to rise. As households start to fully perceive the implications for their permanent wealth, demand increases and tempers the decline in tradable goods price inflation and further stimulates nontradables inflation. The net result is that headline inflation eventually rises above baseline, requiring a tightening in monetary policy. The second, and not unrelated feature, is the behavior of current accounts. Both the Australian and New Zealand current accounts fall, and by significant amounts. The declines reflect increased demand for imports given both increasing wealth and relative declines in import prices. Further, the tightening in monetary policy in response to higher inflation appreciates the exchange rate, further stimulating import demand.

The remainder of the paper is structured as follows. Section II presents a brief overview of GEM and its calibration for this application. Section III examines the historical change in the composition of GDP in Australia, New Zealand and several other industrial countries over the 1995 to 2004 period. Productivity growth over this period, which underlies the simulation experiments, is also examined in this section. The simulation analysis is presented in Section IV. Section V concludes.

\section{An OVerview of The Global ECONOMic Model ${ }^{4}$}

GEM is a multi-country, multi-good macroeconomic model derived completely from optimizing foundations. The version of GEM used here characterizes the behavior of five countries/blocks: Australia, New Zealand, the United States, emerging Asia, and the rest of the world. In each country/region there are households, firms, and a government. Households maximize utility derived from the consumption of goods and leisure. Firms combine capital, and labor, with either commodities or land to maximize the net income from goods production. Governments consume goods financed through non-distorting taxes and adjust short-term nominal interest rates to provide nominal anchors.

\section{A. Households}

Households are infinitely lived, consume goods, and are the monopolistic suppliers of differentiated labor inputs to all domestic firms. Not all households have access to capital markets and those that do not, finance consumption completely from their labor income. Households exhibit habit persistence in their consumption behavior contributing to real rigidities in economic adjustment. Monopoly power in labor supply implies that the wages households receive contain a markup over the marginal rate of substitution between consumption and leisure. Because wage contracts are subject to adjustment costs, aggregate nominal rigidities arise through the wage bargaining process.

\footnotetext{
${ }^{4}$ The interested reader can find the technical details on GEM's basic theoretical structure in Pesenti (2008) and the extensions that include the commodity sector in Lalonde and Muir (2007).
} 
Households own all domestic firms, the domestic capital stock, and the land, which they rent to domestic firms. The markets for capital and land are competitive. Capital accumulation is subject to adjustment costs that also contribute to gradual economic adjustment. Labor and capital are immobile internationally. Households only trade short-term nominal bonds internationally. These bonds are denominated in United States dollars and issued in zero net supply worldwide.

\section{B. Firms}

In the version of the model used here, firms produce three types of goods: nontradable goods; tradable non-commodity goods (manufactures); and tradable non-energy commodity goods (commodities). Commodities are used only as an intermediate input into the production of nontradables and manufactures.

Goods are assumed to be differentiated giving rise to the market power. This condition of monopolistic competition implies that prices may contain a markup over marginal cost. Firms producing nontradables and manufactures combine capital, labor and commodities under CES technology. Firms producing commodities combine capital, labor, and land under CES technology. Prices of goods are subject to adjustment costs that, along with slowly adjusting wages, give rise to the gradual adjustment of prices in response to economic disturbances.

Bundles of nontradables and manufactures are consumed by domestic households or the government, or used for investment. The structure of final goods production reflects preferences over all goods, and thus international trade is driven by the interaction of preferences and relative prices. The bundle of goods consumed by households and governments can differ in import content from the bundle of goods used for investment.

\section{Government}

Government spending falls on nontradables and manufactures. Government spending is financed through a non-distorting tax. The government controls the national short-term nominal interest rate with the objective of providing a nominal anchor for the economy. The nominal anchors in Australia, New Zealand, the United States, and the rest of the world are inflation rates. For emerging Asia, the nominal anchor is stability in the nominal exchange rate between the emerging Asian currency and the U.S. dollar.

\section{Parameterization}

Parameter values for GEM are derived through calibration. Specific parameter values are determined by balancing several factors: empirical estimates available in the literature; the desired steady-state characterization of the economies; and the model's dynamic adjustment properties. The focus of the calibration for this exercise has been the steady-state characteristics, and in particular, the trading relationships among the regions. Because the issue of concern is the underlying trend in the composition of GDP, less attention has been given to the precise calibration of quarterly adjustment dynamics. Nominal and real adjustment cost parameters as well as inflation targeting policy rules are identical in all blocks. However, nominal and real dynamics will differ because of different proportions of liquidity constrained households and different markups in goods and labor markets. Some 
key calibration details are provided in Appendix 1 and the full calibration of the model is available from the author upon request.

\section{The Stylized FaCtS}

A number of adjustments where made to the data before computing the change in the share of goods production between 1995 and 2004. First, goods where defined to be manufactures and commodities. ${ }^{5}$ However, with the large increase in oil prices that has occurred since the end of the 1990's, the production of oil was removed from commodities for Canada, Norway, the United Kingdom, and the United States. To look through the yearly volatility in the data, three-year moving averages of the shares of GDP are considered for all countries except Canada and the United States due to limited data availability. Further, for the United States, a comparable and consistent data set is available only for the 1998 to 2006 period.

New Zealand and Australia, like most industrial countries, have been experiencing a decline in the relative importance of tradable goods production. Goods production as a share of New Zealand GDP declined by 31/4 percentage points between 1995 and 2004, from roughly $281 / 4$ percent to 25 percent. In Australia, the decline was similar, 23/4 percentage points, declining from 24 percent in 1995 to $21 \frac{1}{4}$ percent in 2004 . Some countries under consideration, Norway, Iceland and the United Kingdom, experienced notably larger declines. A couple of countries, South Africa and Sweden, experienced slightly smaller declines. The declines in both Canada and the United States were quite similar to those experienced in New Zealand and Australia.

Figure 1. Share of Tradable Goods Production in GDP
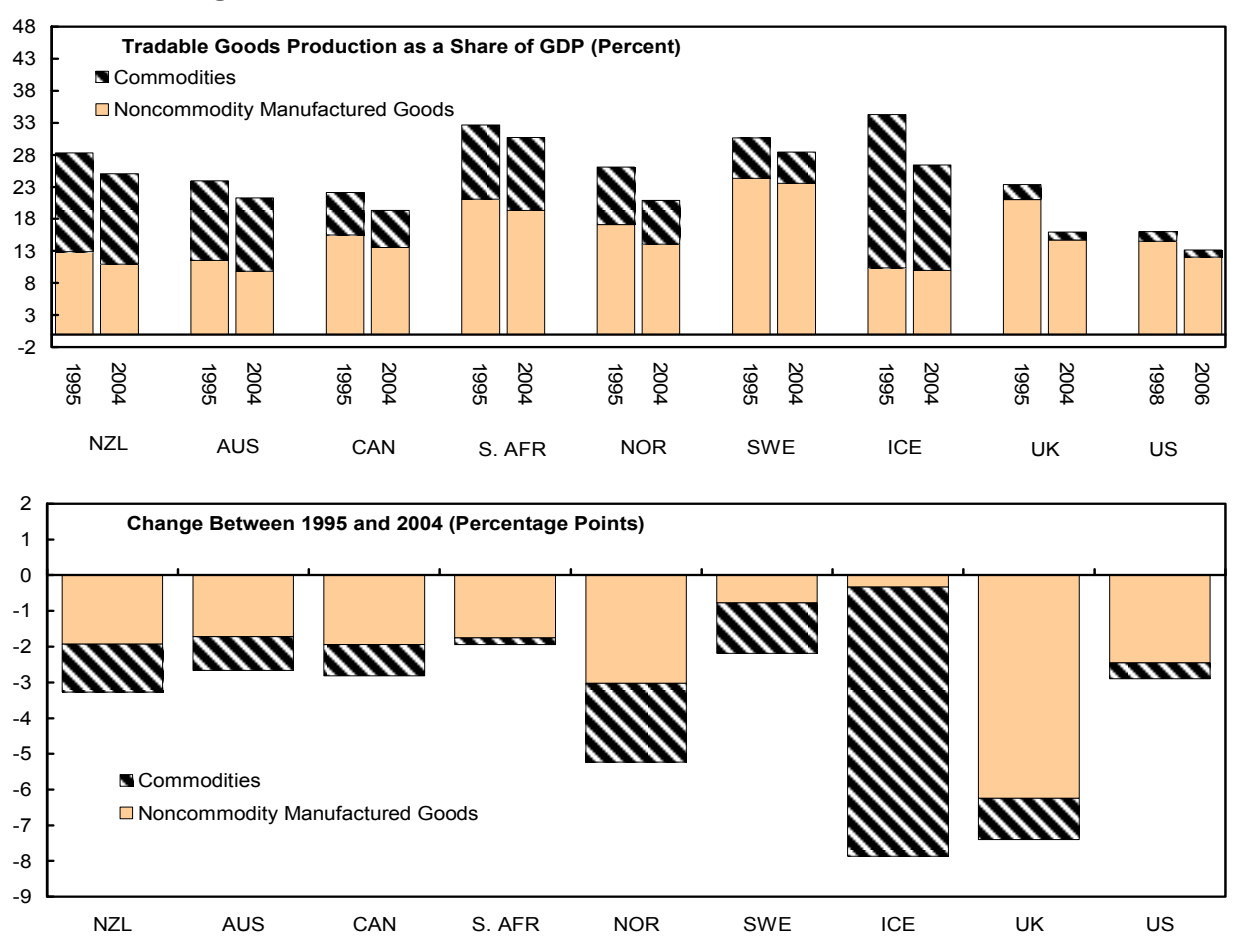

\footnotetext{
${ }^{5}$ Commodities were defined to be agriculture, fishing, forestry, mining and the production of food and beverages. Food and beverages were not included in commodities for South Africa, the U.K. or the U.S.
} 
As noted earlier, Baumol's unbalanced growth theory is often cited as an important factor driving de-industrialization. Baumol (1967) argues that the declining relative importance of goods production can arise from more rapid technological progress in the goods sector. Notionally, there is more scope for adopting labor-saving technological advancements in goods production. Despite faster productivity growth in the goods sector, labor mobility between the goods and services sectors enforces nominal wage equality. The required lower real producer wage in the service sector (because of lower productivity) is achieved with a rising relative price of services and, therefore, an increase in the share of services in output. The open economy extension of Baumol allows for international trade to further drive down the relative price of tradable manufactured goods.

The growth of productivity in the tradable and nontradable sectors in Australia, New Zealand and their major trading partners over the 1995 to 2004 period was in fact quite unbalanced. ${ }^{6}$ The annual growth in labor productivity in the tradables and nontradables sectors for Australia, New Zealand, and their major trading partners/regions are graphed in Figure 2 and summarized in Table 1. Productivity growth has been notably faster in the tradables sector than in nontradables. The average gap between sectors over the ten year period ranges from roughly $1 \frac{1}{2}$ percentage points in Australia and the United States to 4 percentage points in emerging Asia. These productivity growth gaps between the tradable and non-tradable sectors suggest that Baumol's unbalanced growth could be an important contributor to the relative decline in tradable goods production over the 1995 to 2004 period.

Figure 2. Annual Labor Productivity Growth ${ }^{7}$

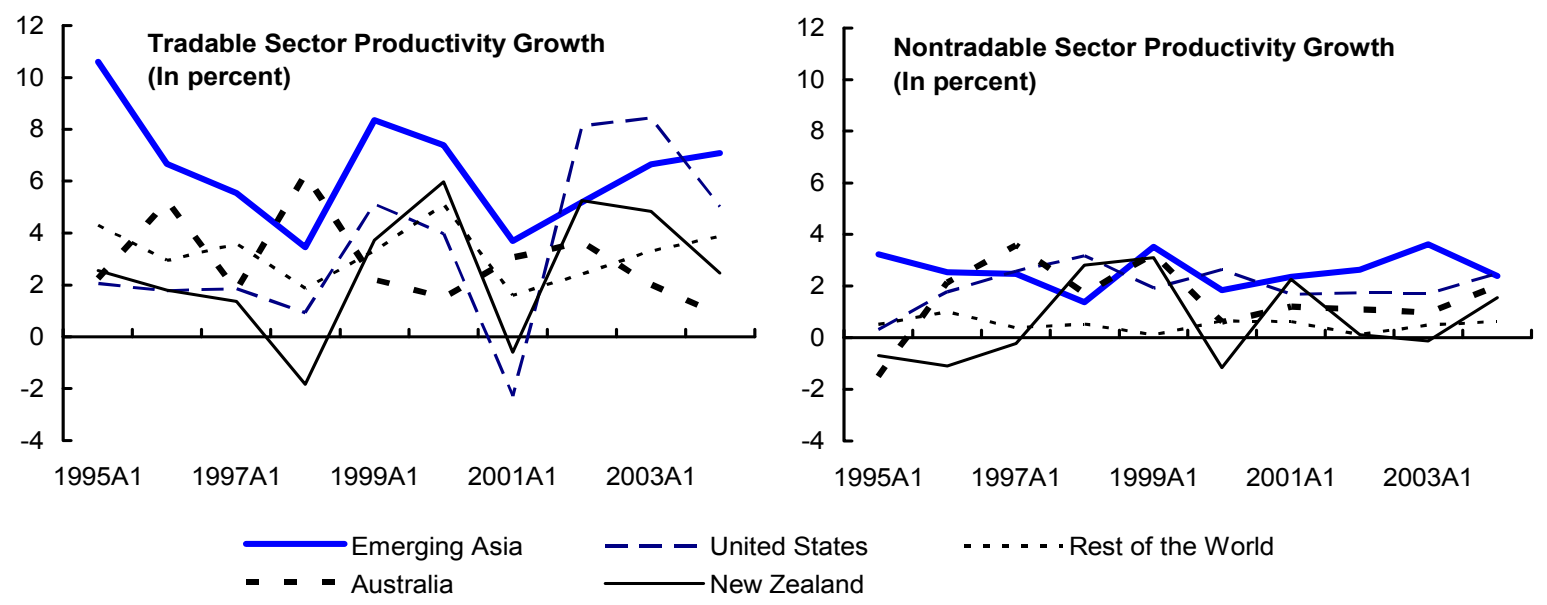

\footnotetext{
${ }^{6}$ Nordhaus (2008) using an industry data set for the United States covering 1948-2001 period finds strong evidence of unbalanced growth as well substantial support for the implications of Baumol' unbalanced growth theory.

${ }^{7}$ These productivity growth rates are derived from the data that supports the CGER assessment of exchange rates which is maintained by the IMF's Research Department. See IMF (2006).
} 
Table 1. Average Annual Labor Productivity Growth 1995 to 2004

\begin{tabular}{lccccc}
\hline & New Zealand & Australia & Emerging Asia & United States & $\begin{array}{c}\text { Rest of } \\
\text { World }^{1}\end{array}$ \\
\hline Tradables & 2.55 & 2.88 & 6.46 & 3.50 & 3.23 \\
Nontradables & 0.65 & 1.50 & 2.59 & 2.0 & 0.50 \\
Productivity Gap & 1.90 & 1.38 & 3.87 & 1.50 & 2.73 \\
\hline
\end{tabular}

${ }^{1}$ The Euro Area, the United Kingdom, and Japan are used to proxy the rest of the world.

\section{Simulation Results}

The experiment is set up to replicate the trend productivity growth gap between the tradable and nontradable sectors in Australia, New Zealand and their major trading partners over the 1995 to 2004 period. The shock is designed so that in each period productivity growth in the tradable sector in each country/region is higher by the average over the ten-year period. It is assumed that the productivity growth gap exists equally in the commodities and manufactures sectors. Ideally the shock would be implemented by matching the actual historical gaps between non-tradables and each of the two tradable goods in the model. However, the available data does not split the tradable goods sector into these two components.

The shock is implemented assuming that people must learn about the persistence in productivity growth. When agents have perfect foresight under long-lived shocks that have significant implications for wealth, rational expectations models, like GEM, can produce adjustment dynamics unlike that seen in actual data. To address this and generate closer-toreal-world adjustment dynamics, the shock is implemented assuming that each period, agents must generate forecasts of the persistence in productivity growth. Here the learning is calibrated so that agents initially learn slowly about the persistence. However, as the duration of the shock increases, agents start to learn more quickly. See Hunt (2007) for a complete description of the uncertainty framework and an illustration of the speed of learning.

\section{A. Some Broad Features of the Simulation Results}

Before turning to look closely at the magnitude of the impact on tradable goods production, it is interesting to look at some of the broad macroeconomic outcomes of the simulation. The dynamic adjustment paths for several key variables in the Australia, New Zealand, and U.S. blocks of the model are presented in Figure 3. With the focus of the calibration having been on the long-term properties and trading relationships with less attention given to the short-run nominal and real rigidities, it is important to focus on the qualitative aspects rather than the precise quantitative aspects of the quarterly adjustment dynamics.

The first point to note is the impact of the productivity growth gap on the level and the composition of GDP. Both the magnitude of the productivity gap and degree of openness matter. With New Zealand having the largest productivity gap of the three, the impact on GDP is the largest in New Zealand. However, openness matters as well as can be seen by the 
fact that the productivity gap was slightly smaller in Australia than in the United States, but the impact on GDP is larger in Australia because it is relatively more open. As GDP rises, the share of tradable goods declines and the share of services increases. Although again the magnitude of the productivity gap matters, so does openness as attested by the larger decline in tradable goods production in Australia relative to the United States.

The second point to note is the relative price implications that underlie the shift in the composition of production. These relative price implications are well illustrated by the decomposition of inflation into its tradable and nontradable components. Service price inflation is well above overall CPI inflation with tradables goods inflation well below in all three countries. The gap between tradables and nontradables inflation is largest in New Zealand and smallest in the United States. Again reflecting the magnitude of the productivity growth gap and the degree of openness.

The third point worth noting is that although CPI inflation initially falls below trend, after 4 or 5 years it rises above. When productivity growth first accelerates, the sharp decline in tradable goods price inflation more than offsets the mild increase in service price inflation. However, as agents learn about the persistence in the increase in productivity growth and its implications for their wealth, demand pressures grow. These pressures offset some of the downward pressures on tradables prices from faster productivity growth and increase pressures on nontradables prices. This leads to CPI inflation rising above baseline and prompting monetary policy to tighten. Headline inflation increases most in the more open economies of New Zealand and Australia where the wealth effects from falling import prices are larger.

The last thing to consider is the current account balance. All three industrial countries' current accounts decline relative to the baseline. Two factors contribute. First, rapidly falling tradable goods prices and their implications for wealth stimulate demand, particularly for imports from emerging Asia and the rest of world, where the acceleration in tradable sector productivity is the largest. Second, the eventual tightening in monetary policy appreciates currencies, further stimulating import demand. Interestingly, these broad features in inflation and current accounts in the simulation match key trends seen in over the 1995 to 2004 period in Australia, New Zealand, and the United States. 
Figure 3. Some Broad Macroeconomic Consequences of Unbalanced Growth

(Percent or Percentage point deviations from baseline)

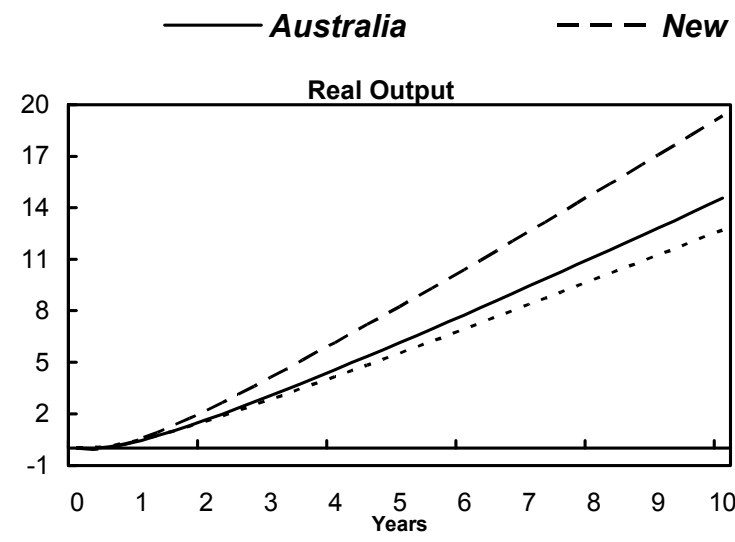

Zealand

..... United States
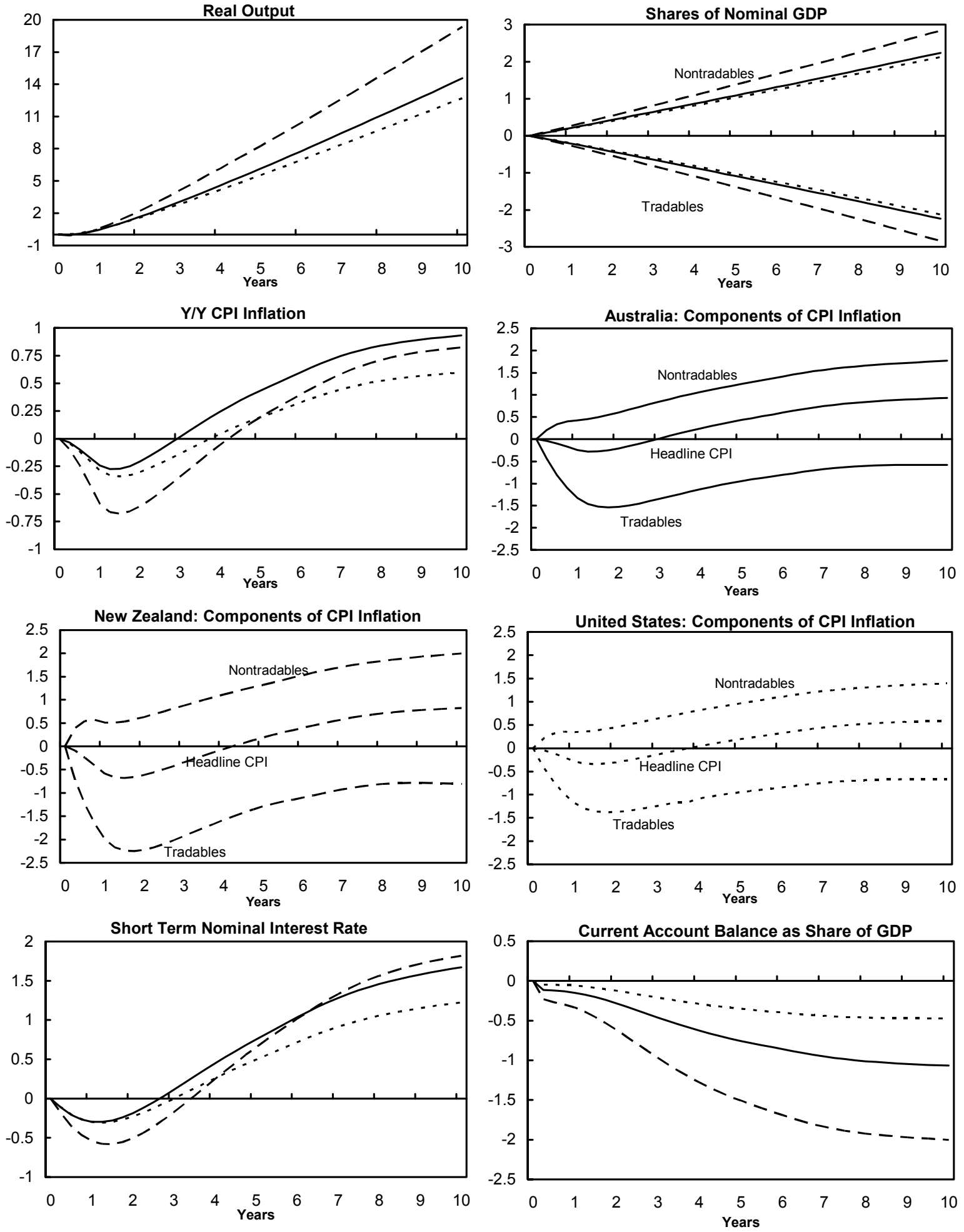

Sources: Gem simulations. 


\section{B. Effect of Unbalanced Growth on Tradables Production}

The declines in the shares of tradable goods in the simulation broadly match the declines seen in the data. The simulated changes in the shares of tradable goods in GDP for New Zealand, Australia and the United States are presented in Table 2 along with the historical declines. In terms of the total decline in the share of tradable goods in GDP, the simulation results match the data surprisingly well for both New Zealand and Australia. In the cases of New Zealand and Australia, the simulated declines are just slightly below what occurred, while for the United States, the simulated decline is only about 75 percent of the decline in the data. This could reflect the fact that the region configuration used here does not adequately capture the trading relationships of most importance for the United States, for example that with Canada.

Table 2. Change Over Ten Years in Share of GDP (In Percent)

\begin{tabular}{lcccccc}
\hline & \multicolumn{2}{c}{ New Zealand } & \multicolumn{2}{c}{ Australia } & \multicolumn{2}{c}{ United States $^{1}$} \\
\cline { 2 - 7 } & Simulated & Actual & Simulated & Actual & Simulated & Actual \\
\hline Manufactures & -1.85 & -1.92 & -1.35 & -1.72 & -2.04 & -2.46 \\
Commodities & -0.99 & -1.34 & -0.89 & -0.95 & -0.09 & -0.43 \\
Total & -2.84 & -3.26 & -2.24 & -2.68 & -2.13 & -2.89 \\
\hline
\end{tabular}

Source: National Accounts data and GEM simulations.

\section{Internal and External Contributions}

It is possible to decompose the results into the decline arising from external factors, trading partner productivity growth, and internal factors, domestic productivity growth. The simulation is simply rerun including only trading partners' productivity growth gaps. The results for Australia, New Zealand and the United States, presented in Table 3, suggest that between one-half and two-thirds is explained by external factors. Not surprisingly, the magnitude of the impact of external factors is a function of openness. External factors account for 69 percent of the simulated decline in New Zealand, 68 percent of the decline in Australia, and 45 percent of the decline in the United States. The remainder of the simulated decline is due to internal factors, the domestic productivity growth gap. However, it is important to note that this decomposition assumes that domestic productivity growth is independent of trading partner productivity growth. If domestic productivity growth is stimulated by trading partner productivity growth, then an even larger share of the relative decline would be attributable to external factors.

These results suggest external factors are more important than some other empirical estimates in the literature. Reduced-form estimates presented Rowthorn and Coutts (2004) using a sample of 23 advanced economies suggest that over the 1992 to 2002 period, between onethird and one-half of the relative decline in manufactures was due to external factors. The differences between the empirical and simulation results may be reconciled by the unexplained component in the simulation results. It could be the case that service demand is 
income elastic. The reduced-form econometric estimates allocate a portion of the decline due to internal factors to an increase in the demand for services generated by rising incomes. ${ }^{8}$ If it is assumed that the unexplained portions in the simulation results are due to changing preferences, then external factors would account for 60 percent in New Zealand, 57 percent in Australia, and 35 percent in the United States, much closer to the estimated range in Rowthorn and Coutts. ${ }^{9}$

Table 3: Simulated Changes Over Ten Years in Share of GDP (In Percent)

\begin{tabular}{lcccccc}
\hline & \multicolumn{2}{c}{ New Zealand } & \multicolumn{2}{c}{ Australia } & \multicolumn{2}{c}{ United States $^{1}$} \\
\cline { 2 - 7 } & Combined & External & Combined & External & Combined & External \\
\hline Manufactures & -1.85 & -1.02 & -1.35 & -0.46 & -2.04 & -0.73 \\
Commodities & -0.99 & -0.93 & -0.89 & -1.06 & -0.09 & -0.22 \\
Total & -2.84 & -1.95 & -2.24 & -1.52 & -2.13 & -0.95 \\
\hline
\end{tabular}

Source: National Accounts data and GEM simulations.

\section{CONCLusions}

Over the 1995 to 2004 period, the share of tradable goods in GDP in Australia and New Zealand declined. Using GEM, this paper illustrates that a large potion of the decline can be explained by the faster productivity growth in the tradable goods sector witnessed over the period in Australia, New Zealand, and their major trading partners. This unbalanced growth explains roughly 85 percent of the decline in both Australia and New Zealand, and roughly 75 percent of the decline in the United States. Further, if it is assumed that the portion unexplained by unbalanced growth is due to income-elastic service demand, the other most often cited theory, then the simulated contributions to the decline attributable to external and internal factors is broadly consistent with other empirical research. Two other broad features of macroeconomic performance in these economies over the period is also roughly captured by the unbalanced growth simulation, mounting service price inflation pressures eventually prompting monetary tightening and declines in current account balances.

\footnotetext{
${ }^{8}$ Although empirical support for service demand being income elastic is mixed, as reported in Falvey and Gemmel (1996), Schettkat (2007) argues that careful analysis of input-output data, National Accounts data, and household expenditure surveys, suggests that service demand is income elastic, particularly household expenditure.

${ }^{9}$ Computed as $1.95 / 3.26$ for New Zealand, 1.52/2.68 for Australia, and $0.95 / 2.89$ for the United States.
} 


\section{REFERENCES}

Baumol, W., 1967, "Macroeconomics of Unbalanced Growth: The Anatomy of Urban Crisis." American Economic Review, June, pp. 415-426.

Baumol, W., A. Blackman, and E. Wolfe, 1989, Productivity and American Leadership: the Long View, The MIT Press, Cambridge, MA.

Clark, C., 1940, The Conditions of Economic Progress, MacMillan \& Co. Ltd., London.

Falvey, R., and N., Gemmel, 1996, "Are Services Income-Elastic? Some New Evidence," Review of Income and Wealth, Vol. 42, No. 3, pp. 257-269.

Freeman, R, and R. Schettkat, 2001, "Marketization of Production and the U.S.-Europe Employment Gap," Oxford Bulletin of Economics and Statistics, Vol. 63, pp 647-670.

Freeman, R, and R. Schettkat, 2005, "Marketization of Household Production and the U.S.Europe Gap in Work," Economic Policy, No.1, pp. 1-27.

Hunt, B., 2007, “U.K. Inflation and Relative Prices Over the Last Decade: How Important was Globalization?” IMF Working Paper, WP/07/208.

International Monetary Fund, 2006, "Methodology for CGER Exchange Rate Assessments," available on the web http://www.imf.org/external/pp/longres.aspx?id=3957.

Lalonde, R., and D. Muir, 2007, “The Bank of Canada's Version of the Global Economy Model," Bank of Canada Technical Report No. 98.

Nordhaus, W., 2008, “Baumol's Disease: A Macroeconomic Perspective,” The B.E. Journal of Macroeconomics, Vol. 8, no. 1.

Schettkat, R., 2007, "The Astonishing Regularity of Service Employment Expansion," Metroeconometrica, Vol. 38, No. 3. pp. 423-435.

Pesenti, P., 2008, “The Global Economy Model: Theoretical Framework” forthcoming in IMF Staff Papers.

Rowthorn R., and K. Coutts, 2004, "De-Industrialization and the Balance of Payments in Advanced Economies," United Nations Conference on Trade and Development, Discussion Paper No. 170.

Rowthorn R., and R. Ramaswamy, 1999, "Growth, Trade and Deindistrialization," IMF Staff Papers, Vol. 46, No. 1, pp. 18-41. 


\section{Appendix I. Calibration Details}

Some of the key steady-state calibration details are provide below. Given the size of the model, only a small number of important ratios and parameter values are listed below. The author will provide model code and all parameters values upon request.

Table 1. Key Steady-State Calibration Values

\begin{tabular}{lccccc}
\hline Variable & Australia & New Zealand & United States & Emerging Asia & Rest of World \\
\hline $\begin{array}{l}\text { Size (sum to 1) } \\
\text { In Percent of GDP }\end{array}$ & 0.013 & 0.002 & 0.330 & 0.100 & 0.555 \\
Priv. Consumption & 54.72 & 58.09 & 65.52 & 55.62 & 56.43 \\
Priv. Investment & 22.17 & 17.75 & 16.71 & 28.82 & 21.27 \\
Government Exp. & 22.50 & 23.20 & 17.50 & 15.80 & 22.40 \\
Exports & 23.29 & 31.92 & 12.23 & 23.43 & 8.33 \\
Imports & 22.70 & 30.97 & 11.97 & 23.68 & 8.45 \\
Tradables & 38.80 & 44.63 & 40.08 & 59.55 & 47.20 \\
Nontradables & 61.20 & 55.37 & 59.92 & 40.45 & 52.80 \\
Net Foreign Assets & 60.00 & 95.00 & -28.00 & 25.00 & Residual \\
\hline
\end{tabular}

Table 2. Non-Commodity Tradables as Percent of GDP

\begin{tabular}{crcccc}
\hline & Australia & New Zealand & United States & Emerging Asia & Rest of World \\
\hline Exports & 12.93 & 11.43 & 10.46 & 21.68 & 7.52 \\
To AUS & & 3.57 & 0.16 & 0.47 & 0.22 \\
To NZL & 0.97 & & 0.02 & 0.12 & 0.04 \\
To U.S. & 0.91 & 0.93 & & 9.41 & 4.36 \\
To E.A. & 5.82 & 2.42 & 2.20 & & 2.91 \\
To R.W. & 5.23 & 4.51 & 8.08 & 11.69 & \\
\hline
\end{tabular}


Table 3. Production and Trade in Commodities as Shares of GDP (In Percent)

\begin{tabular}{lccccc}
\hline & Australia & New Zealand & United States & Emerging Asia & Rest of World \\
\hline Production & 12.8 & 20.89 & 1.62 & 2.27 & 2.20 \\
Exports & 10.3 & 19.60 & 1.50 & 2.06 & 0.77 \\
To AUS & & 2.59 & 0.01 & 0.06 & 0.0 \\
To NZL & 0.3 & & 0.00 & 0.01 & 0.0 \\
To U.S. & 0.4 & 3.11 & & 0.34 & 0.5 \\
To E.A. & 4.1 & 4.57 & 0.29 & & 0.26 \\
To R.W. & 5.5 & 9.31 & 1.20 & 1.65 & \\
\hline
\end{tabular}

Table 4. Key Behavioral Parameter Values

\begin{tabular}{lc}
\hline \multicolumn{1}{c}{ Parameter } & All Countries \\
\hline Elasticity of Substitution Between Manufactures and Nontradables & 0.50 \\
Elasticity of Substitution Across Manufactures & 1.00 \\
Elasticity of Substitution Across Commodities & 10.00 \\
Habit Persistence in Consumption & 0.85 \\
Frisch Labor Elasticity of Substitution & 0.40 \\
Habit Persistence in Labor Supply & 0.75 \\
Elasticity of Substitution in Nontradables and Manufactures Production & 1.00 \\
Elasticity of Substitution in Commodities Production & 0.60 \\
\hline
\end{tabular}

